\title{
The Cell Wall of Seagrasses: Fascinating, Peculiar and a Blank Canvas for Future Research
}

\author{
Lukas Pfeifer and Birgit Classen* \\ Department of Pharmaceutical Biology, Pharmaceutical Institute, Faculty of Mathematics and Natural Sciences, \\ Christian-Albrechts-University of Kiel, Kiel, Germany
}

\section{OPEN ACCESS}

Edited by:

Ugo Cenci,

Lille University of Science and Technology, France

Reviewed by: Iker Irisarri,

University of Göttingen, Germany Julien Le Roy,

La Cité Collégiale, Canada

*Correspondence: Birgit Classen

bclassen@pharmazie.uni-kiel.de

Specialty section:

This article was submitted to Marine and Freshwater Plants,

a section of the journal

Frontiers in Plant Science

Received: 29 July 2020 Accepted: 07 October 2020 Published: 23 October 2020

Citation:

Pfeifer L and Classen B (2020) The Cell Wall of Seagrasses: Fascinating, Peculiar and a Blank

Canvas for Future Research.

Front. Plant Sci. 11:588754.

doi: 10.3389/fp/s.2020.588754
Seagrasses are a polyphyletic group of angiosperm plants, which evolved from early monocotyledonous land plants and returned to the marine environment around 140 million years ago. Today, seagrasses comprise the five families Zosteraceae, Hydrocharitaceae, Posidoniaceae, Cymodoceaceae, and Ruppiaceae and form important coastal ecosystems worldwide. Despite of this ecological importance, the existing literature on adaption of these angiosperms to the marine environment and especially their cell wall composition is limited up to now. A unique feature described for some seagrasses is the occurrence of polyanionic, low-methylated pectins mainly composed of galacturonic acid and apiose (apiogalacturonans). Furthermore, sulfated galactans have been detected in some species. Recently, arabinogalactan-proteins (AGPs), highly glycosylated proteins of the cell wall of land plants, have been isolated for the first time from a seagrass of the baltic sea. Obviously, seagrass cell walls are characterized by new combinations of structural polysaccharide and glycoprotein elements known from macroalgae and angiosperm land plants. In this review, current knowledge on cell walls of seagrasses is summarized and suggestions for future investigations are given.

Keywords: cell wall, seagrass, apiogalacturonan, sulfated polysaccharide, arabinogalactan-protein, lignin

\section{INTRODUCTION}

Around 140 million years ago, seagrasses evolved from early monocotyledonous land plants, which succeeded in conquering the marine environment. Today, they are a polyphyletic group of marine angiosperms with around 60 species in five families (Zosteraceae, Hydrocharitaceae, Posidoniaceae, Cymodoceaceae, and Ruppiaceae), which belong to the order Alismatales according to the Angiosperm Phylogeny Group IV System (APG IV, Chase et al., 2016). The genus Ruppia, which occurs in brackish water, is not regarded as a "real" seagrass by all authors and has been shifted to the Cymodoceaceae by some authors (Les and Tippery, 2013). The APG IV System and The Plant List Webpage (The Plant List, 2020) do not share this family assignment. We included Ruppia in this review to cover all literature with the connection to "seagrass" and used the traditional assignment to Ruppiaceae, resulting in five seagrass families. Seagrasses form important coastal ecosystems (Hemminga and Duarte, 2000). The worldwide endangering of these sea meadows, which provide food and habitat for many marine species, prompts the need for protection and understanding of these valuable resources. Recently, sequencing of the genomes of Zostera marina and 
Zostera muelleri allowed better understanding angiosperm adaption to the sea (Lee et al., 2016; Olsen et al., 2016). During the evolutionary step back to the ocean, different genes have been lost (e.g., stomatal genes) or have been reduced (e.g., genes involved in the synthesis of terpenoids) and others have been regained (e.g., genes involved in sulfation; Olsen et al., 2016). Genome information further revealed that adaption to the marine habitat was accomplished by severe changes of cell wall composition (Lee et al., 2016; Olsen et al., 2016). On the other hand, the cell walls of seagrasses are poorly understood. Beside ancestral traits of land plants, one would anticipate a habitat-driven adaption process to the new environment, which is characterized by multiple abiotic (high amounts of salt) and biotic (different seagrass grazers and bacterial colonization) stressors.

Although knowledge is limited, seagrass cell walls contain polysaccharides known from angiosperm land plants, e.g., cellulose (Syed et al., 2016). On the other hand, the cell walls of some seagrasses are characterized by sulfated polysaccharides (SP) (Aquino et al., 2005; Silva et al., 2012; Kolsi et al., 2016), a common attribute of the macroalgae from the groups of red, brown and also green algae. Recently the ability to synthesize SP was proposed to be regained by marine angiosperms (Aquino et al., 2005). Another unique feature of cell walls of seagrasses is the occurrence of unusual pectic polysaccharides called apiogalacturonans. Characteristic are high amounts of lowmethyl esterified galacturonic acid (GalA $p$ ) units substituted with the unusual monosaccharide apiose (Apif) (Gloaguen et al., 2010; Lv et al., 2015).

In addition to polysaccharides, glycoproteins of the hydroxyproline-rich glycoprotein family (classified in Johnson et al., 2003), are important components of cell walls of land plants. The highly glycosylated arabinogalactan-proteins (AGPs) are interesting due to their involvement in both wall architecture and cellular regulatory processes (Ellis et al., 2010; Ma et al., 2018). AGPs are ubiquitous in seed land plants (Ma et al., 2018) and have also been found in ferns, lycophytes and mosses (Classen et al., 2019). They are structurally characterized by large polysaccharide moieties comprised of arabinogalactans (AGs, normally $>90 \%$ of the molecule) which are covalently linked via hydroxyproline (Hyp) to relatively small protein/peptide backbones (normally around $1-10 \%$ of the molecule). The AGs of seed plants mainly consist of type II $(3,6)$-galactans with 3-, 6-, and 3,6-linked $\beta$-D-galactose $(\mathrm{Gal} p)$ residues, substituted with $\alpha$-L-arabinose (Araf) and often minor amounts of glucuronic acid (GlcAp) residues (Ma et al., 2018). Distinct glycan modifications have been identified in different species and tissues and are suggested to influence both their physical properties and function. Recently, AGPs have been isolated and structurally characterized for the first time from a seagrass (Pfeifer et al., 2020). Although the common backbone structure of land plant AGPs is conserved, the glycan structures exhibit unique features, including a high degree of branching and an unusually high content of terminating 4-O-methyl-glucuronic acid (4-OMe GlcA) residues, suggesting a role of seagrass AGPs in osmoregulation (Lamport et al., 2006).

Further components of secondary walls of plants are crosslinked phenolic polymers called lignin, which are responsible for mechanical strengthening of the wall. In seagrasses, this polymer has also been detected, but often in lower amounts compared to angiosperm land plants (Opsahl and Benner, 1993; Klap et al., 2000; Martone et al., 2009; Kaal et al., 2018).

Thus, cell walls of seagrasses seem to be fascinating combinations of features known from both angiosperm land plants and marine macroalgae with new structural elements. As dried seagrass leaves might be useful for papermaking or as insulating materials, knowledge on their cell wall composition is also important from a technological point of view. This review offers a detailed summary and discussion of literature on cell wall components of seagrasses.

\section{POLYSACCHARIDE COMPONENTS OF SEAGRASS CELL WALLS}

Table 1 gives an overview on isolation and characterization processes described for cell wall polysaccharides from seagrasses. Table 2 shows the already characterized polysaccharide structures from seagrasses.

\section{Cellulose}

Comparable to angiosperm land plants, cellulose is a main component of seagrass cell walls. The content of cellulose has been determined in relation to dry plant material in different genera, e.g., Halodule (Waldron et al., 1989), Halophila (Baydoun and Brett, 1985; Waldron et al., 1989; Syed et al., 2016), Posidonia (Torbatinejad and Sabine, 2001; Torbatinejad et al., 2007; Khiari et al., 2010), Zostera (Davies et al., 2007), Cymodocea, Enhalus and Thalassia (Syed et al., 2016), and found to vary between $20 \%$ in Posidonia australis (Torbatinejad and Sabine, 2001) and 77\% in Enhalus acoroides (Syed et al., 2016). A comparison between roots, leaves and rhizomes of Halodule ovalis, Halodule stipulacea, and Halophila uninervis revealed no obvious differences between the three species; in general, leaf tissue contained more cellulose compared to root and rhizome material (Waldron et al., 1989). It has to be taken into account, that the methods to determine the content of cellulose differ and are therefore difficult to compare (e.g., the method of Moubasher et al., 1982, is used to estimate cellulose, hemicellulose and lignin content in plant material). In general, the content of cellulose is estimated as the amount of insoluble material after hydrolysis. The methods for hydrolysis vary and furthermore, the insoluble residue is sometimes regarded as cellulose content, sometimes the carbohydrate part of the insoluble residue is determined by the photometric method of DuBois et al. (1956). Whereas in some cases only TFA $(2 \mathrm{~N})$ is used for hydrolysis (Waldron et al., 1989), other authors perform TFA (2 N) treatment first followed by further hydrolysis with concentrated sulfuric acid (Davies et al., 2007). In both cases, the sugar content in the insoluble residues is determined photometrically to give the cellulose content. Other authors use alkaline treatment with $\mathrm{KOH}$ (residue A: cellulose and lignin), followed by hydrolysis with strong sulfuric acid (residue B: lignin) and calculate the cellulose content (A-B) without determination of the carbohydrate content (Syed et al., 2016). In none of the literature reviewed, the type of cellulose 
TABLE 1 | Overview on isolation and characterization processes for cell wall polysaccharides from seagrasses.

\begin{tabular}{|c|c|c|c|c|c|c|c|c|}
\hline \multirow[t]{2}{*}{ Species } & \multirow[t]{2}{*}{ Organ } & \multirow[t]{2}{*}{ Isolation } & \multicolumn{5}{|c|}{ Structural analysis } & \multirow[t]{2}{*}{ References } \\
\hline & & & $\begin{array}{l}\text { Monosaccharide } \\
\text { composition }\end{array}$ & FT-IR & NMR & MS & $\begin{array}{l}\text { Biological } \\
\text { activities }\end{array}$ & \\
\hline Amphibolis antarctica & Pollen grain & Enzyme containing buffer & $\sqrt{ }$ & - & - & - & - & Harris et al. (1994) \\
\hline Cymodocea nodosa & Whole plant without root & Hot water after acetone and ethanol preextraction & $\sqrt{ }$ & $\sqrt{ }$ & $\sqrt{ }$ & $\sqrt{ }$ & $\sqrt{ }$ & Kolsi et al. (2016) \\
\hline Halodule pinifolia & n.s. ${ }^{1}$ & Hot water after depigmentation with acetone & - & $\sqrt{ }$ & - & - & $\sqrt{ }$ & Kannan et al. (2013) \\
\hline Halodule uninervis & Leaves, rhizomes, roots & $\begin{array}{l}\text { Sodium acetate buffer }(10 \mathrm{mM}) \text {, containing } \mathrm{CaCl}_{2}(3 \mathrm{mM}) \\
\text { and adjusted to } \mathrm{pH} 5.0\end{array}$ & $\sqrt{ }$ & - & - & - & - & $\begin{array}{l}\text { Baydoun and Brett (1985); } \\
\text { Waldron et al. (1989) }\end{array}$ \\
\hline Halodule wrightii & n.s. ${ }^{1}$ & $\begin{array}{l}\text { Sodium chloride solution }(0.25 \mathrm{M}) \text { adjusted to } \mathrm{pH} 8.0 \text { after } \\
\text { depigmentation with acetone }\end{array}$ & $\sqrt{ }$ & $\sqrt{ }$ & - & - & $\sqrt{ }$ & Silva et al. (2012) \\
\hline Halophila ovalis & Leaves, rhizomes, roots & $\begin{array}{l}\text { Sodium acetate buffer }(10 \mathrm{mM}) \text { containing } \mathrm{CaCl}_{2}(3 \mathrm{mM}) \\
\text { and adjusted to } \mathrm{pH} 5.0\end{array}$ & $\sqrt{ }$ & - & - & - & - & Baydoun and Brett (1985) \\
\hline Halophila stipulacea & Leaves, rhizomes, roots & $\begin{array}{l}\text { Sodium acetate buffer }(10 \mathrm{mM}) \text { containing } \mathrm{CaCl}_{2}(3 \mathrm{mM}) \\
\text { and adjusted to } \mathrm{pH} 5.0\end{array}$ & $\sqrt{ }$ & - & - & - & - & Baydoun and Brett (1985) \\
\hline Posidonia australis & Leaves, whole plant & Hot sulfuric acid, 0.4 N; directly from plant material & $\sqrt{ }$ & - & - & - & - & $\begin{array}{l}\text { Bell et al. (1954); Torbatinejad } \\
\text { et al. (2007); Torbatinejad and } \\
\text { Sabine (2001) }\end{array}$ \\
\hline Ruppia maritima & Leaves, rhizomes, roots & Papain-containing buffer at $\mathrm{pH} 6.0$ & $\sqrt{ }$ & - & $\sqrt{ }$ & - & - & Aquino et al. (2005) \\
\hline Heterozostera tasmanica & Root hairs & $\begin{array}{l}\text { Washed cell walls directly hydrolyzed in } 4 \%(\mathrm{w} / \mathrm{v}) \text { sulfuric } \\
\text { acid }\end{array}$ & $\sqrt{ }$ & - & - & - & - & Webster and Stone (1994) \\
\hline Phyllospadix torreyi & n.s. ${ }^{1}$ & Hot water, $5 \%$ ammonium oxalate, $7 \%$ sodium hydroxide & $\sqrt{ }$ & $\sqrt{ }$ & - & - & - & Woolard and Jones (1978) \\
\hline Zostera marina & n.s. ${ }^{1}$; Leaves, rhizomes, roots & $\begin{array}{l}1 \%(\mathrm{w} / \mathrm{v}) \text { aqueous ammonium oxalate with following } \\
\text { pectinase treatment; aqueous extract and } \\
\text { Yariv-precipitation after depigmentation with acetone }\end{array}$ & $\sqrt{ }$ & - & $\sqrt{ }$ & $\sqrt{ }$ & $\sqrt{ }$ & $\begin{array}{l}\text { Gloaguen et al. (2010); Pfeifer } \\
\text { et al. (2020) }\end{array}$ \\
\hline Zostera caespitosa & n.s. ${ }^{1}$ & Ammonium oxalate, $2 \%(\mathrm{w} / \mathrm{v})$ & $\sqrt{ }$ & $\sqrt{ }$ & $\sqrt{ }$ & $\sqrt{ }$ & $\sqrt{ }$ & Lv et al. (2015) \\
\hline
\end{tabular}

If more than one publication focused on one species, both are described in the "Isolation" column below each other. ${ }^{1}$ not specified plant organ used for extraction. 
TABLE 2 | Structurally described charged polysaccharides from seagrasses.

$\begin{array}{lll}\begin{array}{l}\text { Major monosaccharide } \\ \text { components }{ }^{1}\end{array} & \text { Linkages }\end{array}$

O

○

1,4-linked Gal, 6-O-sulfated

Kolsi et al. (2016)

not enough data

文

$\ominus$

0

1,4-linked GalA; 1,3-linked Api

Lv et al. (2015)

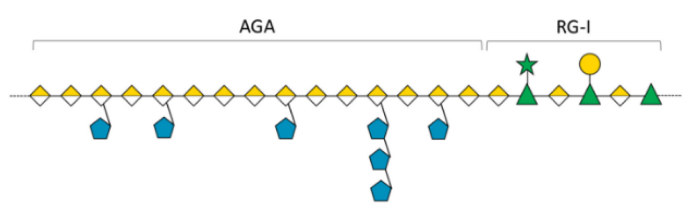

$\triangle$

tr

not determined

Silva et al. (2012)

not enough data

$\bigcirc$

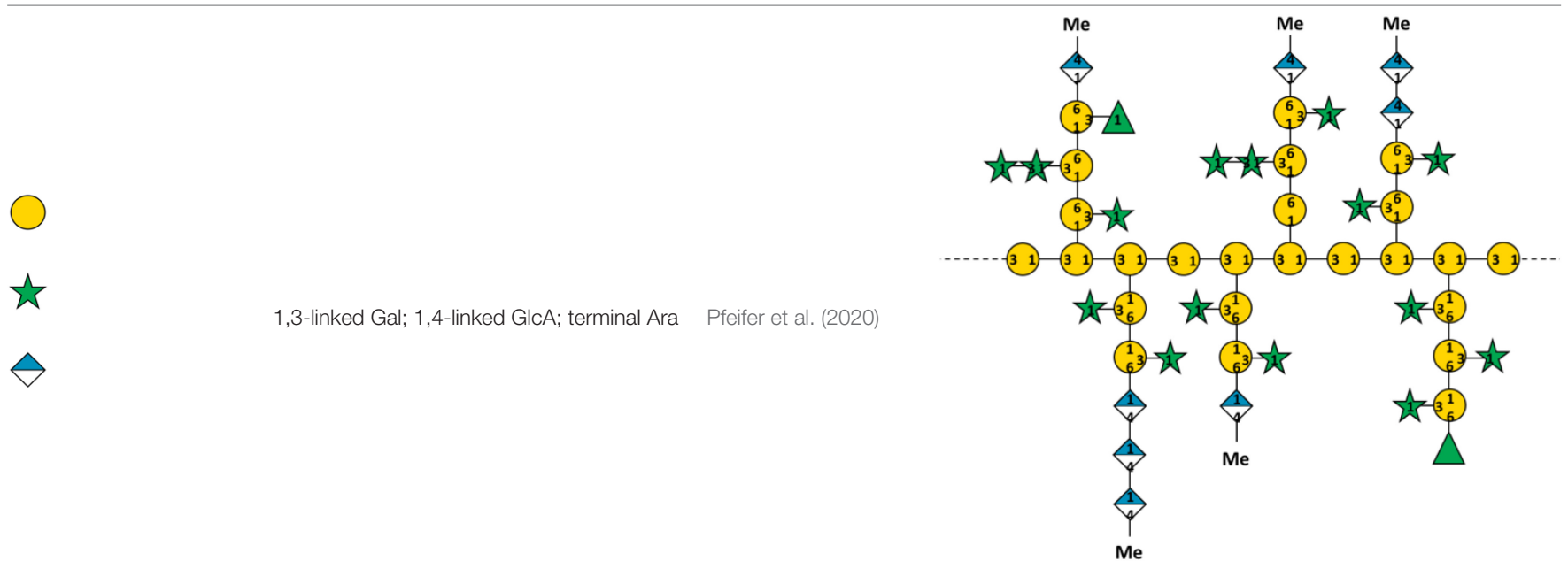

Major polysaccharide components are symbolized using the Symbol Nomenclature for Glycans (SNFG) of the NCBI-Glycan Page (National Center for Biotechnology Information (NCBI), 2020). Abbreviations: Api, apiose; Ara, arabinose; Gal, galactose; GalA, galacturonic acid; and GlcA, glucuronic acid. ${ }^{1}$ monosaccharides are treated as "major" if they contribute more than $10 \%$ of the polysaccharide. 
( $\alpha$ - or $\beta$-cellulose) was determined. To gain more information on that, it is recommended to perform a fractionated extraction (Galiwango et al., 2019) and use the different solubility of both types in alkaline conditions.

\section{Hemicelluloses}

Hemicelluloses are a large family of cell wall polysaccharides including different polymers. Syed et al. (2016) estimated the amount of hemicelluloses in different seagrasses using the method of Moubasher et al. (1982). The values ranged from $14-28 \%$ of dried seagrass material (Thalassia hemprichii 14\%, Halophila spinulosa 23\%, Cymodocea serrulata 26\%, Halophila ovalis, and Enhalus acoroides 28\%). For Posidonia australis (Torbatinejad et al., 2007; Torbatinejad and Sabine, 2001) and Posidonia oceanica balls (Khiari et al., 2010) the amounts were 11.7 and $21.8 \%$, respectively. Highest values for hemicelluloses were determined for Z. marina (38\%; Davies et al., 2007).

\section{Xylans}

Xylans are a group of plant cell wall polysaccharides with a backbone consisting of 1,4-linked $\beta$-D-xylopyranoses, which have a high degree of substitution (York and O'Neill, 2008; Hatfield et al., 2016; Peña et al., 2016; Tryfona et al., 2019). Xylans are the main hemicelluloses in the cell walls of most plant species (Tryfona et al., 2019) and play an important role in crosslinking with other structural components (cellulose, lignin). In primary cell walls of plants belonging to the Poales (also monocotyledonous plants), xylans are present in high amounts.

Most of the publications on seagrass xylans are based on crude monosaccharide quantification; investigations on exact structures of seagrass xylans are missing. Baydoun and Brett (1985) could show that significant quantities of xylose and arabinose were present in non-cellulosic polysaccharide fractions of Halophila stipulacea and $H$. ovalis and attributed this to presence of arabinoxylans. In the same study, Halodule uninervis showed only small amounts of xylose in the same cell wall fraction. In support of this finding, Brudecki et al. (2015) measured a low xylan content of around 5\% for cell walls of H. uninervis with similar methods. On the other hand, Z. marina fibers contain $38 \%$ hemicelluloses, which are mainly xylans (Davies et al., 2007). Are they complex heteroxylans like in grasses or more similar to algal 1,4-linked- (charophytic green algae), 1,3-linked- (chlorophytic green algae/some red algae), or 1,3; 1,4-linked-homoxylans (red algae) (Hsieh and Harris, 2019)? The next step forward to answer this question would be a broader investigation: Modern methods like xylan epitope profiling (Peralta et al., 2017), capillary electrophoresis based high-throughput carbohydrate profiling (Li et al., 2013), solidstate NMR methods (e.g., Dupree et al., 2015) or HILIC-MALDIToF/ToF-MS/MS (Busse-Wicher et al., 2016) have to be carried out to give insights in xylan structure of seagrasses.

\section{Mannans}

Mannans are important members of the hemicellulose family, which are subdivided into linear mannans, galacto-, gluco- and galactoglucomannans (Petkowicz et al., 2001; Moreira and Filho, 2008). They have mainly structural functions, but also signaling functions are proposed (Moreira and Filho, 2008). They are present in eukaryotic algal species belonging to the divisions of Rhodophyta and Chlorophyta, where they seem to replace cellulose as the main cell wall carbohydrate (Painter, 1983). To the best of our knowledge, there are no described mannans in any seagrass species. He et al. (2015) postulated a correlation of mannan accumulation in Dendrobium officinale with water deficiency stress. Even though $D$. officinale is not a marine plant, this phenomenon could be also apparent in seagrass species. More studies with a focus on mannans are necessary to answer the question whether mannans are components of seagrass cell walls.

\section{Xyloglucans}

Xyloglucans are found in primary cell walls of all angiosperms, where they are responsible for the crosslinking of cellulose microfibrils (Popper and Fry, 2008; Brennan and Harris, 2011). They consist of 1,4-linked $\beta$-D-glucose residues which form a backbone substituted with $\alpha$-D-xylosyl chains at O-6. Xyloglucans with the special side chain $\alpha$-L-Fucp$(1,2)-\beta-\mathrm{D}-\mathrm{Gal} p-(1,2)-\alpha-\mathrm{D}-\mathrm{Xyl} p-(1,6)-\beta-\mathrm{D}-\mathrm{Gl} p \rho$ are called fucogalactoxyloglucans and are common in primary walls of non-commelinid monocotyledons, while they are rare in commelinids. In a study with the monoclonal antibody CCRCM1, which recognizes the epitope structure $\alpha$-Fuc- $(1,2)-\beta$-Gal, Zostera muelleri interestingly differs in its fucogalactoxyloglucan composition from the other investigated non-commelinid monocotyledons. While most of the investigated noncommelinid species showed a widely distributed fluorescence labeling with this antibody comparable to Arabidopsis thaliana, $Z$. muelleri was labeled only in the phloem sieve elements (Brennan and Harris, 2011).

The low amount of fucogalactoxyloglucan in Zostera muelleri (Brennan and Harris, 2011) is supported by the fact that in the genome of another Zostera species there were only 2 GT37 genes, which encode the xyloglucan fucosyltransferases (Olsen et al., 2016). In contrast to that, Arabidopsis or Oryza have 10 or 18 of these enzyme genes, respectively.

\section{Mixed-Linked Glucans}

The so-called mixed linked glucans (MLG), consisting of $\beta$-Dglucose chains connected through 1,3- and 1,4-linkages, have been found in high amounts in the Poales order (Popper and Fry, 2004), in Centraria islandica (as "lichenan;" Stone and Clarke, 1992), in the genus Equisetum (Fry et al., 2008) and most recently in Phaeophyceae cell walls (Salmean et al., 2017). In the Poales order MLG is present at certain stages during the primary wall formation in maize (Penning et al., 2019). Baydoun and Brett (1985) as well as Waldron et al. (1989) attributed the high amounts of glucose in Halodule uninervis to the presence of MLG. Structure elucidation has to be performed to prove this proposal.

\section{Pectic Polysaccharides}

Pectin is a structurally complex carbohydrate family rich in galacturonic acid, including the major polysaccharides homogalacturonan, rhamnogalacturonan I, rhamnogalacturonan 
II and xylogalacturonan (for an in-depth review, see Mohnen, 2008). Their characteristically high amount of acidic domains is important for the osmotic properties and can interact with ions and low-molecular-weight compounds (Willats et al., 2001).

In some seagrasses, a special pectic polysaccharide named "apiogalacturonan" is present (Table 2). Miroshnikov (1940) first isolated an uronic acid rich polysaccharide with gelforming properties from $Z$. marina, which he named "zosterine." Analytical characterization of zosterine was broadened by the studies of the group of Ovodova and Ovodov (e.g., Ovodova et al., 1968; Ovodov et al., 1971a,b, 1975; Popov et al., 2007), which detected $\mathrm{D}$-apiose as substantial monosaccharide of this pectic fraction.

Recent studies (Gloaguen et al., 2010; Lv et al., 2015) investigated the fine structure of apiogalacturonans in two different Zostera species after extensive purification steps. Its structure was analyzed with modern instrumentation (enzymatic digestion + mass spectrometry of fractions; one- and twodimensional NMR experiments). The described structures consist of an $\alpha$-1,4-linked-D-galacturonan substituted at position C-2 or C-3 of GalA by single apiose residues or short oligosaccharides of apiofuranose (Table 2).

Apiogalacturonans of seagrasses have a very low degree of esterification around 10\% (Maeda et al., 1966; Khotimchenko et al., 2012). Recent genetic studies of two Zostera species (Lee et al., 2016; Olsen et al., 2016) revealed an increase in unique pectin methylesterase-related domains in different proteins possibly responsible for the low degree of methylesterification. It is hypothesized that this represents a control mechanism for osmoregulation. Furthermore, investigations on heavy metal binding by apiogalacturonans (e.g., cerium and mercury, Khotimchenko et al., 2006, 2012; cadmium and lead, Khozhaenko et al., 2016) might help to understand biophysiological functions of apiogalacturonans in "high-charge environments" like the marine habitat.

Arabinans are composed of a $\alpha-1,5$-linked arabinofuranose backbone and may occur separately in the wall or as neutral side chains of rhamnogalacturonan-I (Wefers and Bunzel, 2016). Although an "arabinan" content has been described for Halodule uninervis (Brudecki et al., 2015) only a very crude compositional analysis was performed in this investigation. Whether seagrasses contain arabinans is therefore unknown to date and needs to be investigated in more detail (e.g., by a fast approach with a combination of two-dimensional NMR spectroscopy with previous enzyme-assisted extraction, like established by Wefers and Bunzel, 2016).

\section{Sulfated Polysaccharides}

Sulfated polysaccharides have been found in a number of marine organisms (e.g., Pomin, 2012; Ngo and Kim, 2013) and are often described as compounds with a number of bioactivities, including antioxidant, anticancer and anticoagulant activities (Ngo and Kim, 2013). Their occurrence is mostly correlated with a saline environment (Aquino et al., 2011).

In 2005, SP were first detected in the seagrasses Halodule wrightii and Halophila decipiens as well as in the marine angiosperm Ruppia maritima (Aquino et al., 2005) in amounts around $1 \%(\mathrm{~m} / \mathrm{m})$. Structure elucidation was performed only for the galactan from $R$. maritima and revealed a 2-Oand 4-O-sulfated galactan, which consists of a repeating tetrasaccharide [3- $\beta$-D-Gal-2(OSO 3$)-1,4-\alpha-\mathrm{D}-\mathrm{Gal}-1,4-\alpha-\mathrm{D}-\mathrm{Gal}-$ $1,3-\beta-\mathrm{D}-\mathrm{Gal}-4\left(\mathrm{OSO}_{3}\right)$ ] (Table 2 and Figure 1$)$. In an additional study from the same working group (Aquino et al., 2011) it was shown, that the amount of this SP increased in higher salinity and disappeared in culture without salt supplement.

Silva et al. (2012) postulated the presence of a sulfated heteropolysaccharide in $H$. wrightii, consisting of glucose:xylose:galactose (1:1:0.9) with a sulfation degree of $20 \%$ and a molecular weight of $\sim 11 \mathrm{kDa}$. As the sample was treated with trichloroacetic acid (10\%) during the isolation process (Table 1), which is, to the best of our knowledge, a polysaccharide-degrading and sulfate-deleting condition, the presence of this SP in Halodule has to be verified by further investigations.

Occurrence of a "fucoidan-like sulfated polysaccharide" has been proposed for Halodule pinifolia (Kannan et al., 2013). The structural data has to be regarded as preliminary as it based only on Fourier-Transformation infrared spectroscopic (FT-IR) analysis and colorimetric total sugar determination.

A sulfate containing polysaccharide fraction has been isolated from Cymodocea nodosa by water-extraction followed by ethanol-precipitation (Kolsi et al., 2016). Structural analytics (NMR, LC-ESI-MS) led to the proposal of a branched 1,4linked galactosidic backbone with 6-O-sulfation and decoration with small amounts of other monosaccharides. Due to the isolation procedure (see above), the sulfated galactan is most likely accompanied by other water-soluble polysaccharides.

\section{Callose}

Callose is a homopolysaccharide composed of $\beta(1,3)$-linked glucose with some $\beta(1,6)$-branches which is typically found in sieve plate pores, in plasmodesmata, in the cell plate during cell division and also in pollen (Wu et al., 2018). It is synthesized by callose synthase (Verma and Hong, 2001) and plays an important role in biotic and abiotic stress response (Lampugnani et al., 2018). An easy method to detect callose in light microscopy is anilin blue fluorochrome staining of plant tissue. Whereas the pollen walls of Amphibolis antarctica showed no staining with anilin blue (Ducker et al., 1978; Harris et al., 1994), callose staining was positive between daughter cells in the pollen tetrads of T. hemprichii and T. ciliatum. Callose was also detected by this staining in pollen of $H$. wrightii and $Z$. marina (Pettit and Jermy, 1975). As reaction with this dye is not exclusive for callose (Smith and McCully, 1978), more specific methods for detection should be applied like e.g., the use of the monoclonal antibody $\mathrm{AB} 400-2$. With this antibody, detection of $\beta(1,3)$ - in the presence of $\beta(1,4)$ - or $\beta(1,3)-\beta(1,4)$-linked glucan structures is possible (Meikle et al., 1991) and it was also used for immunolocalization of callose in streptophyte green algae (Herburger and Holzinger, 2015). A hint of the general ability of at least some seagrasses to synthesize callose is the presence of "Glucan synthase-like 8" genes in Halophila and two Zostera species (Lee et al., 2018). In Arabidopsis, these genes encode enzymes responsible for callose synthesis. 

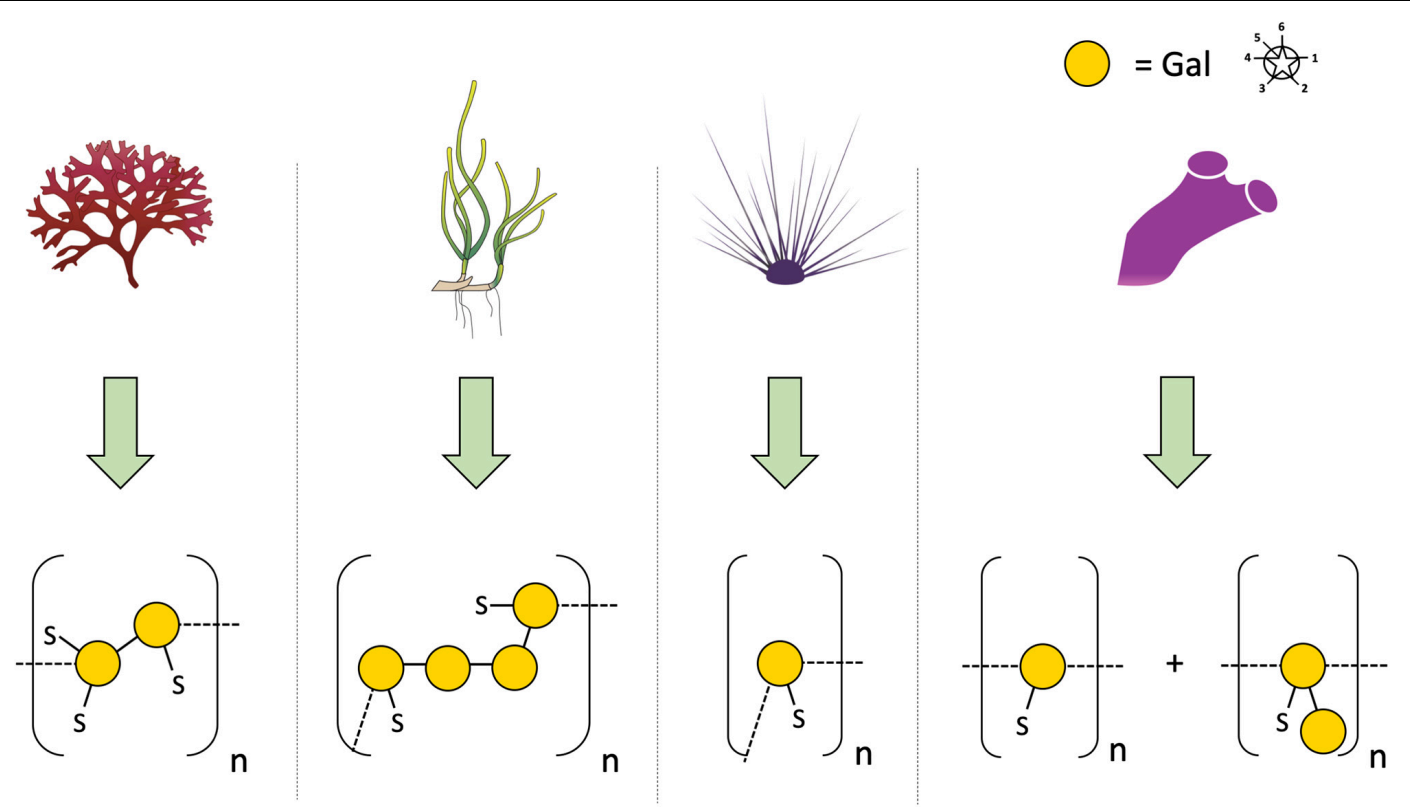

FIGURE 1 | Diverse structures of sulfated galactans from marine organisms. Sulfated polysaccharide structures from left to right: red algae: Botryocladia occidentalis, seagrass: Ruppia maritima, sea urchin: Echinometra lucunter, tunicate: Styela plicata. Illustration adapted from Aquino et al. (2005). All vector images are from Tracey Saxby, Jane Thomas, Jane Hawkey, IAN Image Library (ian.umces.edu/imagelibrary/).

\section{WALL (GLYCO)PROTEINS}

As Johnson et al. (2003) proposed, the term "wall protein" is used in this review to refer to all types of glycosylated proteins, despite their degree of glycosylation or protein-glycosylation type. The literature about this group of biomolecules from seagrasses is mainly limited to some works on pollen cell walls. Ducker and Knox (1976) first proposed the presence of specialized "glycoproteins" in pollen cell walls of Amphibolis antarctica as a unique adaption to be able to fulfil submarine pollination sufficiently. Based on this hypothesis Pettitt (1980) performed microscopy of T. hemprichii fresh-frozen pollen with $\beta$-glucosyl Yariv ( $\beta$ GlcY) - a reagent used for selective interaction with AGPs. AGPs, which are a group of highly glycosylated (O-linkage via hydroxyproline) proteins are involved in many plant cell wall functions and processes (Ellis et al., 2010). T. hemprichii pollen walls showed positive interaction with $\beta$ GlcY. In discrepancy to that, Harris et al. (1994) performed extraction of Amphibolis antarctica pollen walls and concluded absence of hydroxyproline-rich glycoproteins - a group of wall proteins, including the extensins, AGPs and proline-rich proteins. "Small amounts of glycin-rich proteins [...] may be present" (Harris et al., 1994). These assumptions were based on monosaccharide and amino acid composition of acidic wall preparations. Pfeifer et al. (2020) performed the first isolation and structural characterization of a $\beta$ GlcY-precipitable AGP from Z. marina (Table 2). Here whole plants, rhizomes, roots and leaves were extracted and investigated. In addition to that microscopic data and thermodynamic binding analysis showed that unique 1,4-linked- and terminal-glucuronic acids in this AGP fraction showed calcium binding properties with a $K_{\mathrm{D}}$ value in a micromolar range. This observation underlines the proposed functionality of AGPs in salt adaption (Lamport et al., 2006). A broader investigation on presence in other seagrass species could be of scientific value, especially in the light of independent adaption to the sea in minimum three seagrass lineages (Williams, 2016).

As far as $N$-linked glycosylated wall proteins are concerned, the only work on a seagrass was done by Yoshiie et al. (2012) showing that $Z$. marina contains high-mannose type $N$-glycans in high amounts. These $\mathrm{N}$-linked glycans also possess a wide range of functions intensively discussed by Strasser (2014).

\section{LIGNIN}

Beside the polysaccharide components, the secondary walls of vascular land plants consist of condensed macromolecules with cross-linked phenolic monomers, called lignin. These polymers are described as containing about $30 \%$ of the organic carbon in biosphere (Boerjan et al., 2003). Due to their molecular structure, their ability to covalently complex with wall polysaccharides and their tendency to encrust cellulose microfibrils, they contribute to increasing hydrophobia in secondary plant walls which results in dehydration. An effect of this process is the gain of mechanical strength and reduction of flexibility for the tissue and for the whole plant (Doblin et al., 2010; Weng and Chapple, 2010).

For a long time, it was not clear whether seagrasses commonly have lignins as cell wall components, because it was hypothesized that due to the experimental methodology other phenols, being present in many seagrass tissues (Lewis and Yamamoto, 1990), could appear as "lignin." Therefore, it was stated that "evidence 


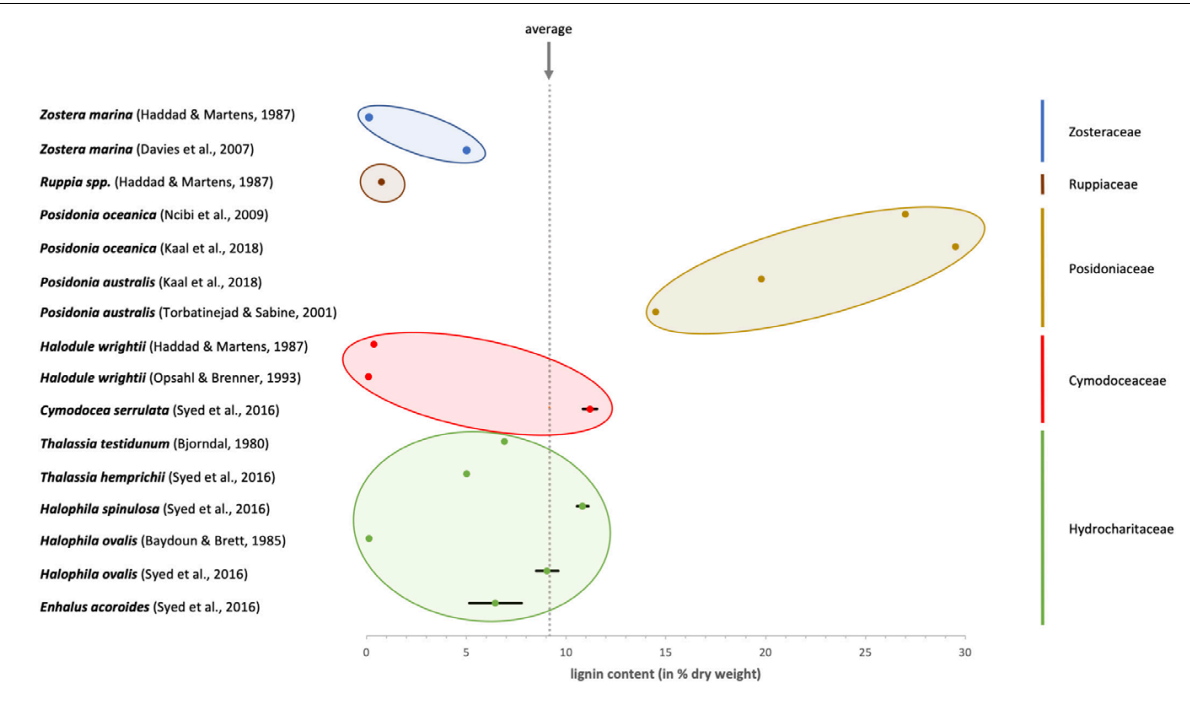

FIGURE 2 | Overview about the published values for lignin content in different seagrass species. The colors identify the membership to the five systematic families of seagrasses.

for lignin in submerged aquatic plants is not convincing. More definitive proof is necessary if these are to be considered lignin-synthesizing organisms" (Lewis and Yamamoto, 1990). Furthermore, there is no consistency in the methodologies of the existing literature. On the other hand, investigation of two seagrass species (Posidonia oceanica and Z. marina) and different tissues of these with Curie-point pyrolysis gas chromatography mass spectrometry (Py-GCMS) revealed that lignin is present in these seagrasses with variations between species and tissues (Opsahl and Benner, 1993; Klap et al., 2000). The retention of lignin during evolution from terrestrial vascular plants back to the sea might be as a useless artifact or an evolutionary advantage also in marine environment. The first idea is questionable due to the recently described occurence of lignin or lignin-like macromolecules in red algae and aquatic green algae (Martone et al., 2009). The second proposal is more conclusive. This topic is discussed intensively by Klap et al. (2000), who found that rhizomes of seagrasses are richer in lignin compared to leaves and suggested that lignification contributes to the longevity of a tissue by protecting it against microbial attack.

According to Syed et al. (2016) the amount of lignin in species of the genera Enhalus, Cymodocea, Halophila and Thalassia is low with $5-11 \%$ of dry weight. In that work, the insoluble residue after treatment with $24 \%$ potassium hydroxide followed by strong sulfuric acid was quantified as lignin.

Looking at the published data (see Figure 2), it seems as if the species belonging to the Posidoniaceae contain more lignin compared to all the other families (Cymodoceaceae, Hydrocharitaceae, Ruppiaceae, and Zosteraceae) which can be regarded as low in lignin content. It has to be taken into account that Posidoniaceae species are responsible for extensive detritus production. As exact definition of material used is missing in some publications, results might be influenced by degraded materials, which contain higher amounts of lignin. Therefore, results on Posidonia balls (e.g., Khiari et al., 2010), which are not comparable to the fresh Posidonia material, were excluded from Figure 2.

Knowledge about lignin is also of interest, because recent publications on blue carbon stocks (Barry et al., 2018; Serrano et al., 2020) showed need of lignin data for their calculations.

\section{INFORMATION ON CELL WALL RELEVANT GENES}

With the increasing field of -omics studies more and more data is accessible, which can be used for nearly each kind of comparison between marine angiosperms and other plant groups or in the polyphyletic group of seagrasses itself. Up to now two full genome sequences have been published. The authors compared the genomes of Z. marina (Olsen et al., 2016) or Z. muelleri ssp. capricornii (Lee et al., 2016), respectively, with the only other sequenced relative from the order of Alismatales, Spirodela polyrhiza and in addition to that to some angiosperm land plants. These two publications gave insight into the molecular adaptation steps to marine environment and supported that severe changes in cell wall composition were necessary.

Sablok et al. (2018) provided access to a transcriptomics database called "SeagrassDB", which allows authors to perform comparative trancriptomics on eight seagrass species and other aquatic plant species. With the same idea Wissler et al. (2009) implemented the "Dr. Zompo" database, which is focused on Z. marina and Posidonia oceanica. Both resources could enable specialists on different cell wall components to test their hypotheses, regarding for example the variety of carbohydrate active enzymes (Table 3 ).

For a detailed overview about molecular profiling and - omics techniques with a full list of all accessible data on seagrasses until the year 2016, see Davey et al. (2016). 
TABLE 3 | Enzymes with activities in biosynthesis of the different cell wall components.

\begin{tabular}{|c|c|c|c|}
\hline Cell wall component & Species & Enzymes* & References \\
\hline Cellulose & Z. marina & 12 CESA; 4 CSLG & Olsen et al. (2016) \\
\hline Xylans & Z. marina & 9 GH3; 3 GH10; 1 GH51; 39 GT8; 10 GT14; 36 GT47; 13 GT61; 1 CE6 & Olsen et al. (2016) \\
\hline Mannans & Z. marina & 6 CSLA; 3 CSLD; 4 GT5_7 & Olsen et al. (2016) \\
\hline \multirow[t]{2}{*}{ Xyloglucans } & Z. marina & 3 CSLC; GH16; 5 GT34; 2 GT37 & Olsen et al. (2016) \\
\hline & Zostera & Xyloglucan endotransglucosylase/hydrolase 5 & Lee et al. (2018) \\
\hline Mixed-linked glucans & Z. marina & absent & Olsen et al. (2016) \\
\hline Pectins & Z. marina & 39 GT8; 36 GT47; 56 GH28; 16 PL1; 63 CE8 & Olsen et al. (2016) \\
\hline Sulfated polysaccharides & Z. marina & to be further investigated & Olsen et al. (2016) \\
\hline \multirow[t]{2}{*}{ Callose } & Z. marina & 19 CBM43; 40 GH17; 10 GT48; & Olsen et al. (2016) \\
\hline & Zostera & Glucan synthase-like 8 & Lee et al. (2018) \\
\hline Wall (glyco-)proteins & Z. marina & 4 DUF579; 14 GT14; 25 GT31; 4 GT61; 13 GT77 & Pfeifer et al. (2020) \\
\hline Lignin & Z. marina & not investigated & \\
\hline
\end{tabular}

*Activities were used as stated in the respective reference.

\section{TECHNICAL APPLICATIONS}

Large amounts of different seagrasses wash on beaches of the world each year, sometimes causing even environmental problems. Therefore, an economic use of this resource would be desirable. For Posidonia australis, use as foodstuff for ruminant animals has been proposed (Torbatinejad et al., 2007). Another possible application of seagrass material is use as source of fibres. Today, pulp production from non-wood material increases, sometimes due to shortage of hard-wood fiber material (Saijonkari-Pahkala, 2008). Use of seagrass material for papermaking has been evaluated for different seagrass species, e.g., Z. marina (Davies et al., 2007), P. oceanica (Khiari et al., 2010), E. acoroides, C. serrulata, H. ovalis, H. spinulosa, and T. hemprichii (Syed et al., 2016). The comparable low lignin content is an advantage as bleaching costs are lower. Among the species investigated by Syed et al. (2016), Enhalus acoroides was most preferable for papermaking because of the highest cellulose content combined with the longest fibers. Another interesting feature of dry seagrass material is its suitability as environmentally friendly, fire-resistant insulating material. Already at the beginning of the 20th century, wild gathering of the leaves of $Z$. marina formed the basis of an insulation industry in North America (Wyllie-Echeverria and Cox, 1999). Today, there are efforts to revive this industry, e.g., Posidonia oceanica balls are gathered and sold as insulating material. Their thermophysical behavior seems to be very promising for this purpose and only a few pre-treatment steps with sodium hydroxide could enhance the properties of Posidonia fibers to a level comparable to industrial insulating materials (Hamdaoui et al., 2018). Another approach for construction purposes has been registered for patent in 2018 (Pavlakis, 2018). The patent holder sells environmentally friendly panels build from Posidonia seagrass balls. Furthermore, the combination of a relatively high amount of cellulose and hemicelluloses together with a low lignin content makes seagrasses an interesting starting material for the production of biofuel. For this kind of use lignin usually has to be removed to enable successful chemical or enzymatic degradation in acceptable yields (Mukherjee et al.,
2016). This approach was proposed for Z. marina detritus in Turkey (Ncibi et al., 2014).

\section{CONCLUSION AND PERSPECTIVES}

\section{Conclusion With Regard to Existing Work}

Despite the ecological importance of seagrasses, which form important coastal ecosystems worldwide, the seagrass cell wall as a whole is poorly understood. The content of cellulose, hemicelluloses and lignin is often estimated by simple procedures using different hydrolytic methods and weighing of the residual material. On the other hand, some detailed investigations of single seagrass polysaccharides in single species shed light on some aspects of seagrass cell wall adaption to the marine habitat (e.g., Aquino et al., 2005; Gloaguen et al., 2010; Lv et al., 2015; Pfeifer et al., 2020). All together, similarities and differences between the different seagrass families and species and also the comparison to cell walls of monocotyledonous land plants are still a mystery.

Especially the hemicelluloses are poorly investigated up to now. Although a content of over $30 \%$ in relation to dry plant material has sometimes been estimated for these polysaccharides, most publications comprise only rough determinations of components without in-detail structural elucidations like it is state-of-the-art in this particular field of cell wall research. For technical applications, knowledge on cellulose content and nature of hemicelluloses are necessary to evaluate the suitability of seagrass material for papermaking or production of biofuels.

With regard to pectic polysaccharides, the presence of apiogalacturonans not known from land plants has been shown for two Zostera species (Gloaguen et al., 2010; Lv et al., 2015). Up to now it is unknown whether apiose-rich carbohydrates are only limited to a few seagrass species or a general feature, being relevant for angiosperm life in the marine habitat.

Another unique feature of seagrass cell walls might be the presence of SP. A sulfated galactan from Ruppia maritima has been isolated and carefully characterized (Aquino et al., 2005). Although there are some proposals for the presence of other 
SP in seagrasses (e.g., Aquino et al., 2011; Silva et al., 2012; Kolsi et al., 2016), proof of sulfate by colorimetric assays or FT-IR is not sufficient, as seagrasses contain other sulfated compounds like e.g., zosteric acid or sulfated flavonoids (Zidorn, 2016). According to Olsen et al. (2016), an expansion of arylsulfotransferases in Zostera compared to land plants might correlate with the ability to synthesize SP. Careful evaluation whether SP are a general feature of seagrasses is urgently needed.

In the field of wall proteins, the recent findings from our group (Pfeifer et al., 2020) could underline the hypothesis of an involvement of highly charged AGPs in calcium storage and signaling (Lamport et al., 2006; Lamport et al., 2020). To answer the question whether AGPs are present in other seagrass species and whether they are structurally comparable to Zostera AGP is another challenge for the future.

Although a high number of literature on lignin in seagrasses is available, more definite proof with modern methodologies, like Py-GC-MS (e.g., procedure of van Erven et al., 2017) or qNMR (e.g., procedure of Capanema et al., 2005) is necessary with a focus on more species from all seagrass families.

\section{Main Challenges for the Future}

At first, comprehensive approaches on evaluation of seagrass cell wall composition are needed to understand the general composition of the cell walls of these angiosperms living in an extreme environment. This could be done by sequential extraction of seagrass material following published protocols (e.g., O'Rourke et al., 2015; Raimundo et al., 2016) and analytical characterization of the different cell wall fractions. To get information on similarities and differences between the cell walls of different seagrass families, so many species as possible, belonging to the different seagrass families, have to be investigated. It has to be taken into account, that the availability of seagrass material is often limited due to the strict rules for protection of seagrasses in their natural habitats.

Furthermore, it has to be investigated whether the interesting unique polysaccharides/glycoproteins which have been isolated and carefully characterized for single seagrass species are

\section{REFERENCES}

Aquino, R. S., Grativol, C., and Mourão, P. A. S. (2011). Rising from the Sea: correlations between sulfated polysaccharides and salinity in plants. PLoS One 6:e18862. doi: 10.1371/journal.pone.0018862

Aquino, R. S., Landeira-Fernandez, A. M., Valente, A. P., Andrade, L. R., and Mourão, P. A. S. (2005). Occurrence of sulfated galactans in marine angiosperms: evolutionary implications. Glycobiology 15, 11-20. doi: 10.1093/ glycob/cwh 138

Barry, S. C., Bianchi, T. S., Shields, M. R., Hutchings, J. A., Jacoby, C. A., and Frazer, T. K. (2018). Characterizing blue carbon stocks in Thalassia testidunum meadows subjected to different phosphorus supplies: a lignin biomarker approach. Limnol. Oceanogr. 63, 2630-2646. doi: 10.1002/lno.10965

Baydoun, E. A.-H., and Brett, C. T. (1985). Comparison of cell wall composition of the rhizomes of three seagrasses. Aquat. Bot. 23, 191-196. doi: 10.1016/03043770(85)90065-8

Bell, D. J., Isherwood, F. A., and Hardwick, N. E. (1954). D(+)-Apiose from the monocotyledon, Posidonia australis. J. Chem. Soc. 3702-3706. also present in other or even all seagrasses. Especially the apiogalacturonans (Gloaguen et al., 2010; Lv et al., 2015), sulfated galactans (Aquino et al., 2005) and highly charged AGPs (Pfeifer et al., 2020) are interesting candidates for adaption to the marine habitat. Comparable to marine algae, charged polysaccharides/glycoproteins of the cell wall seem to be essential to cope with salt stress. A future task will be to elucidate the adaption strategies of the different seagrass lineages that evolved to marine environment independently. Furthermore, the cellular mechanisms involved in protection against salt have to be investigated. Both sulfate groups and uronic acids are able to bind $\mathrm{Ca}^{2+}$ ions, which play a crucial role in both the regulation of transport and exclusion of $\mathrm{Na}^{+}$and other mineral ions at the plasma membrane of plant cells and are able to protect a salt-sensitive species (Phaseolus vulgaris) against damage caused by $\mathrm{NaCl}$ present in the cell culture medium (Lahaye and Epstein, 1969). For AGPs of Z. marina, a strong binding of $\mathrm{Ca}^{2+}$ has already been shown by bio-layer interferometry (Pfeifer et al., 2020).

Finally, full genome sequencing of more seagrass species is necessary to get widespread information on cell wall related genes of these fascinating organisms. Identification of seagrass genes involved in adaption of cell walls to salt water could provide information how agricultural crops might tolerate an increasingly dry and saline environment.

\section{AUTHOR CONTRIBUTIONS}

LP and BC performed literature search and evaluated the published data. LP created tables and figures. Both authors discussed the results and wrote the final manuscript. Both authors contributed to the article and approved the submitted version.

\section{FUNDING}

We acknowledge financial support by University of Kiel and by DFG within the funding program "Open Access Publizieren”.

Boerjan, W., Ralph, J., and Baucher, M. (2003). Lignin biosynthesis. Annu. Rev. Plant Biol. 54, 519-546. doi: 10.1146/annurev.arplant.54.031902.134938

Brennan, M., and Harris, P. J. (2011). Distribution of fucosylated xyloglucans among the walls of different cell types in monocotyledons determined by immunofluorescence microscopy. Mol. Plant 4, 144-156. doi: 10.1093/mp/ ssq067

Brudecki, G., Farzanah, R., Cybulska, I., Schmidt, J. E., and Thomsen, M. H. (2015). Evaluation of composition and biogas production potential from seagrasss (Halodule uninervis) native to Abu Dhabi. Energy Procedia 75, 760-766. doi: 10.1016/j.egypro.2015.07.508

Busse-Wicher, M., Li, A., Silveira, R. L., Pereira, C. S., Tryfona, T., Gomes, T. C. F., et al. (2016). Evolution of xylan substitution patterns in gymnosperms and angiosperms: implications for xylan interaction with cellulose. Plant Physiol. 171, 2418-2431. doi: 10.1104/pp.16.00539

Capanema, E. A., Balakshin, M. Y., and Kadla, J. F. (2005). Quantitative characterization of a hardwood milled wood lignin by nuclear magnetic resonance spectroscopy. J. Agric. Food Chem. 53, 9639-9649. doi: 10.1021/ jf0515330 
Chase, M. W., Christenhusz, M. J. M., Fay, M. F., Byng, J. W., Judd, W. S., Soltis, D. E., et al. (2016). An update of the Angiosperm Phylogeny Group classification for the orders and families of flowering plants: APG IV. Bot. J. Linn. Soc. 181, 1-20. doi: 10.1111/boj.12385

Classen, B., Baumann, A., and Utermoehlen, J. (2019). Arabinogalactan-proteins in spore-producing land plants. Carbohydr. Polym. 210, 215-224. doi: 10.1016/ j.carbpol.2019.01.077

Davey, P. A., Pernice, M., Sablok, G., Larkum, A., Lee, H. T., Golicz, A., et al. (2016). The emergence of molecular profiling and omics techniques in seagrass biology; furthering our understanding of seagrasses. Funct. Integr. Genomics 16, 465-480. doi: 10.1007/s10142-016-0501-4

Davies, P., Morvan, C., Sire, O., and Baley, C. (2007). Structure and properties of fibres from sea-grass (Zostera marina). J. Mater. Sci. 42, 4850-4857. doi: 10.1007/s10853-006-0546-1

Doblin, M. S., Pettolino, F., and Bacic, A. (2010). Plant cell walls: the skeleton of the plant world. Funct. Plant Biol. 37, 357-381. doi: 10.1071/FP09279

DuBois, M., Gilles, K. A., Hamilton, J. K., Rebers, P. A., and Smith, F. (1956). Colorimetric method for determination of sugars and related substances. Anal. Chem. 28, 350-356. doi: 10.1021/ac60111a017

Ducker, S. C., and Knox, R. B. (1976). Submarine pollination in seagrasses. Nature 263, 705-706. doi: 10.1038/263705a0

Ducker, S. C., Pettitt, J. M., and Knox, R. B. (1978). Biology of Australian seagrasses: pollen development and submarine pollination in Amphibolis antarctica and Thalassodendron ciliatum (Cymodoceaceae). Aust. J. Bot. 26, 265-285. doi: 10.1071/BT9780265

Dupree, R., Simmons, T. J., Mortimer, J. C., Patel, D., Iuga, D., Brown, S. P., et al. (2015). Probing the molecular architecture of Arabidopsis thaliana secondary cell walls using two-and three-dimensional ${ }^{13} \mathrm{C}$ solid state nuclear magnetic resonance spectroscopy. Biochemistry 54, 2335-2345. doi: 10.1021/bi501552k

Ellis, M., Egelund, J., Schultz, C. J., and Bacic, A. (2010). Arabinogalactan-Proteins: key regulators at the cell surface? Plant Physiol. 153, 403-419. doi: 10.1104/pp. 110.156000

Fry, S. C., Nesselrode, B. H. W. A., Miller, J. G., and Mewburn, B. R. (2008). Mixed-linkage $(1 \rightarrow 3,1 \rightarrow 4)-\beta$-D-glucan is a major hemicellulose of Equisetum (horsetail) cell walls. New Phytol. 179, 104-115. doi: 10.1111/j.1469-8137.2008. 02435.x

Galiwango, E., Abdel Rahman, N. S., Al-Marzouqi, A. H., Abu-Omar, M. M., and Khaleel, A. A. (2019). Isolation and characterization of cellulose and $\alpha$-cellulose from date palm biomass waste. Heliyon 5:e02937. doi: 10.1016/j.heliyon.2019. e02937

Gloaguen, V., Brudieux, V., Closs, B., Barbat, A., Krausz, P., Sainte-Catherine, O., et al. (2010). Structural characterization and cytotoxic properties of an apiose-rich pectic polysaccharide obtained from the cell wall of the marine phanerogam Zostera marina. J. Nat. Prod. 73, 1087-1092. doi: 10.1021/ np100092c

Hamdaoui, O., Ibos, L., Mazioud, A., Safi, M., and Limam, O. (2018). Thermophysical characterization of Posidonia Oceanica marine fibers intended to be used as an insulation material in Mediterranean buildings. Constr. Build. Mater. 180, 68-76. doi: 10.1016/j.conbuildmat.2018.05.195

Harris, P. J., Webster, J., Weinhandl, J. A., and Stone, B. A. (1994). Composition of the walls of pollen grains of the seagrass Amphibolis antarctica. Sex. Plant Reprod. 7, 101-106. doi: 10.1007/BF00230578

Hatfield, R. D., Rancour, D. M., and Marita, J. M. (2016). Grass cell walls: a story of cross-linking. Front. Plant Sci. 7:2056. doi: 10.3389/fpls.2016.02056

He, C., Zhang, J., Liu, X., Zeng, S., Wu, K., Yu, Z., et al. (2015). Identification of genes involved in biosynthesis of mannan polysaccharides in Dendrobium officinale by RNA-seq analysis. Plant Mol. Biol. 88, 219-231. doi: 10.1007/ s11103-015-0316-z

Hemminga, M. A., and Duarte, C. M. eds (2000). "Seagrasses in the human environment," in Seagrass Ecology (Cambridge: Cambridge University Press), $248-291$.

Herburger, K., and Holzinger, A. (2015). Localization and quantification of callose in the streptophyte green algae Zygnema and Klebsormidium: correlation with desiccation tolerance. Plant Cell Physiol. 56, 2259-2270. doi: 10.1093/pcp/ pcv139

Hsieh, Y. S. Y., and Harris, P. J. (2019). Xylans of red and green algae: what is known about their structures and how they are synthesised? Polymers 11:354. doi: $10.3390 /$ polym 11020354
Johnson, K. L., Jones, B. J., Bacic, A., and Schultz, C. J. (2003). The fasciclinlike arabinogalactan proteins of Arabidopsis. A multigene family of putative cell adhesion molecules. Plant Physiol. 133, 1911-1925. doi: 10.1104/pp.103. 031237

Kaal, J., Serrano, O., Del Río, J. C., and Rencoret, J. (2018). Radically different lignin composition in Posidonia species may link to differences in organic carbon sequestration capacity. Org. Geochem. 124, 247-256. doi: 10.1016/j.orggeochem. 2018.07.017

Kannan, R. R. R., Arumugam, R., and Anantharaman, P. (2013). Pharmaceutical potential of a fucoidan-like sulphated polysaccharide isolated from Halodule pinifolia. Int. J. Biol. Macromol. 62, 30-34. doi: 10.1016/j.ijbiomac.2013. 08.005

Khiari, R., Mhenni, M. F., Belgacem, M. N., and Mauret, E. (2010). Chemical composition and pulping of date palm rachis and Posidonia oceanica-a comparison with other wood and non-wood fibre sources. Bioresour. Technol. 101, 775-780. doi: 10.1016/j.biortech.2009.08.079

Khotimchenko, M. Y., Lenskaya, K. V., Petrakova, M. Y., Khotimchenko, Y. S., and Kovalev, V. V. (2006). The mercury binding activity of pectin isolated from the seagrass Zostera marina. Russ. J. Mar. Biol. 32:312. doi: 10.1134/ S1063074006050099

Khotimchenko, Y., Khozhaenko, E., Kovalev, V., and Khotimchenko, M. (2012). Cerium binding activity of pectins isolated from the seagrasses Zostera marina and Phyllospadix iwatensis. Mar. Drugs 10, 834-848. doi: 10.3390/md100 40834

Khozhaenko, E., Kovalev, V., Podkorytova, E., and Khotimchenko, M. (2016). Removal of the metal ions from aqueous solutions by nanoscaled low molecular pectin isolated from seagrass Phyllospadix iwatensis. Sci. Total Environ. 565, 913-921. doi: 10.1016/j.scitotenv.2016.01.108

Klap, V. A., Hemminga, M. A., and Boon, J. J. (2000). Retention of lignin in seagrasses: angiosperm that returned to the sea. Mar. Ecol. Prog. Ser. 194, 1-11. doi: $10.3354 /$ meps 194001

Kolsi, R. B. A., Fakhfakh, J., Krichen, F., Jribi, I., Chiarore, A., Patti, F. P., et al. (2016). Structural characterization and functional properties of antihypertensive Cymodocea nodosa sulfated polysaccharide. Carbohydr. Polym. 151, 511-522. doi: 10.1026/j.carbpol.2016.05.098

Lahaye, P. A., and Epstein, E. (1969). Salt toleration by plants. Enhancement with calcium. Science 166, 395-396. doi: 10.1126/science.166.3903.395

Lamport, D. T. A., Kieliszewski, M. J., and Showalter, A. M. (2006). Salt stress upregulates periplasmic arabinogalactan proteins: using salt stress to analyse AGP function. New Phytol. 169, 479-492. doi: 10.1111/j.1469-8137.2005. 01591.x

Lamport, D. T. A., Tan, L., Held, M., and Kieliszewski, M. J. (2020). Phyllotaxis turns over a new leaf-A new hypothesis. Int. J. Mol. Sci. 21:1145. doi: 10.3390/ ijms21031145

Lampugnani, E. R., Khan, G. A., Somssich, M., and Persson, S. (2018). Building a plant cell wall at a glance. J. Cell Sci. 131:jcs207373. doi: 10.1242/jcs.207373

Lee, H. T., Golicz, A. A., Bayer, P. E., Jiao, Y., Tang, H., Paterson, A. H., et al. (2016). The genome of a southern hemisphere seagrass species (Zostera muelleri). Plant Physiol. 172, 272-283. doi: 10.1104/pp.16.00868

Lee, H. T., Golicz, A. A., Bayer, P. E., Severn-Ellis, A. A., Chan, C.-K. K., Batley, J., et al. (2018). Genomic comparison of two independent seagrass lineages reveals habitat-driven convergent evolution. J. Exp. Bot. 69, 3689-3702. doi: 10.1093/jxb/ery147

Les, D. H., and Tippery, N. P. (2013). "In time and with water.the systematics of alismatid monocotyledons," in Early Events in Monocot Evolution, eds P. Wilkin and S. J. Mayo (Cambridge: Cambridge University Press), 118-164.

Lewis, N. G., and Yamamoto, E. (1990). Lignin: occurrence, biogenesis and biodegradation. Annu. Rev. Plant Physiol. Plant Mol. Biol. 41, 455-496. doi: 10.1146/annurev.pp.41.060190.002323

Li, X., Jackson, P., Rubtsov, D. V., Faria-Blanc, N., Mortimer, J. C., Turner, S. R., et al. (2013). Development and application of a high throughput carbohydrate profiling technique for analyzing plant cell wall polysaccharides and carbohydrate active enzymes. Biotechnol. Biofuels 6:94. doi: 10.1186/17546834-6-94

Lv, Y., Shan, X., Zhao, X., Cai, C., Zhao, X., Lang, Y., et al. (2015). Extraction, isolation, structural characterization and anti-tumor properties of an apigalacturonan-rich polysaccharide from the sea grass Zostera caespitosa Miki. Mar. Drugs 13, 3710-3731. doi: 10.3390/md13063710 
Ma, Y., Zeng, W., Bacic, A., and Johnson, K. (2018). "AGPs through time and space," in Annual Plant Reviews online, ed. J. A. Roberts (Hoboken, NJ: John Wiley and Sons).

Maeda, M., Koshikawa, M., Nisizawa, K., and Takano, K. (1966). Cell wall constituents, especially pectic substance of a marine phanerogam Zostera marina. Bot. Mag. Tokyo 79, 422-426. doi: 10.15281/jplantres1887. 79.422

Martone, P. T., Estevez, J. M., Lu, F., Ruel, K., Denny, M. W., Somerville, C., et al. (2009). Discovery of lignin in seaweed reveals convergent evolution of cell-wall architecture. Curr. Biol. 19, 169-175. doi: 10.1016/j.cub.2008.12.031

Meikle, P. J., Bonig, I., Hoogenraad, N. J., Clarke, A. E., and Stone, B. A. (1991). The location of $(1 \rightarrow 3)$ - $\beta$-glucan-specific monoclonal antibody. Planta $185,1-8$. doi: $10.1007 / \mathrm{BF} 00194507$

Miroshnikov, V. I. (1940). Zostera as an industrial raw material. Zh. Prikl. Khim. 13, 1477-1489.

Mohnen, D. (2008). Pectin structure and biosynthesis. Curr. Opin. Plant Biol. 11, 266-277. doi: 10.1016/j.pbi.2008.03.006

Moreira, L. R. S., and Filho, E. X. F. (2008). An overview of mannan structure and mannan-degrading enzyme systems. Appl. Microbiol. Biotechnol. 79, 165-178. doi: 10.1007/s00253-008-1423-4

Moubasher, M. H., Abdel-Hafez, S. H., and Mohanram, A. A. (1982). Direct estimation of cellulose, hemicellulose, lignin. J. Agric. Res. 46, 1467-1476.

Mukherjee, A., Mandal, T., Ganguly, A., and Chatterjee, P. K. (2016). Lignin degradation in the production of bioethanol-A review. ChemBioEng Rev. 3, 86-96. doi: 10.1002/cben.201500016

National Center for Biotechnology Information (NCBI) (2020). Glycans Page. Available online at: www.ncbi.nlm.nih.gov/glycans/snfg.html (accessed September 22, 2020).

Ncibi, M. C., Hamissa, A. M. B., and Gaspard, S. (2014). "Plantae and marine biomass for biofuels," in Biomass for Sustainable Applications: Pollution Remediation and Energy, eds S. Gaspard and M. C. Ncibi (Cambridge: RSC Publishing), 290-334.

Ngo, D.-H., and Kim, S.-K. (2013). Sulfated polysaccharides as bioactive agents from marine algae. Int. J. Biol. Macromol. 62, 70-75. doi: 10.1016/j.ijbiomac. 2013.08.036

Olsen, J. L., Rouzé, P., Verhelst, B., Lin, Y.-C., Bayer, T., Collen, J., et al. (2016). The genome of the seagrass Zostera marina reveals angiosperm adaptation to the sea. Nature 530, 331-338. doi: 10.1038/nature16548

Opsahl, S., and Benner, R. (1993). Decomposition of senescent blades of the seagrass Halodule wrightii in a subtropical lagoon. Mar. Ecol. Prog. Ser. 94, 191-205. doi: 10.3354/meps094191

O’Rourke, C., Gregson, T., Murray, L., Sadler, I. H., and Fry, S. C. (2015). Sugar composition of the pectic polysaccharides of charophytes, the closest algal relatives of land-plants: presence of 3-O-methyl-D-galactose residues. Ann. Bot. 116, 225-236. doi: 10.1093/aob/mcv089

Ovodov, Y. S., Mikheyskaya, L. V., Ovodova, R. G., and Krasikova, I. N. (1971a). The pectic substances of Zosteraceae: part V. Smith degradation of zosterine. Carbohydr. Res. 18, 319-322. doi: 10.1016/S0008-6215(00) 80356-0

Ovodov, Y. S., Ovodova, R. G., Bondarenko, O. D., and Krasikova, I. N. (1971b). The pectic substances of Zosteraceae: part IV. Pectinase digestion of zosterine. Carbohydr. Res. 18, 311-318. doi: 10.1016/S0008-6215(00)80355-9

Ovodov, Y. S., Ovodova, R. G., Shibaeva, V. I., and Mikheyskaya, L. V. (1975). Further structural studies of zosterine. Carbohydr. Res. 42, 197-199. doi: 10. 1016/S0008-6215(00)84117-8

Ovodova, R. G., Vaskovsky, V. E., and Ovodov, Y. S. (1968). The pectic substances of zosteraceae. Carbohydr. Res. 6, 328-332. doi: 10.1016/S0008-6215(00) 81454-8

Painter, T. J. (1983). “4-Algal polysaccharides," in The Polysaccharides, ed. G. O. Aspinall (Cambridge: Academic Press), 195-285.

Pavlakis, L. (2018). Environmentally friendly panel from the dead seagrass leaves of Posidonia oceanica. International Patent PCT/GR2017/000043

Peña , M. J., Kulkarni, A. R., Backe, J., Boyd, M., O’Neill, M. A., and York, W. S. (2016). Structural diversity of xylans in the cell walls of monocots. Planta 244, 589-606. doi: 10.1007/s00425-016-2527-1

Penning, B. W., McCann, M. C., and Carpita, N. C. (2019). Evolution of the cell wall families of Grasses. Front. Plant Sci. 10:1205. doi: 10.3389/fpls.2019.01205
Peralta, A. G., Venkatachalam, S., Stone, S. C., and Pattathil, S. (2017). Xylan epitope profiling: an enhanced approach to study organ developmentdependent changes in xylan structure, biosynthesis, and deposition in plant cell walls. Biotechnol. Biofuels 10:245. doi: 10.1186/s13068-017-0935-5

Petkowicz, C. L. O., Reicher, F., Chanzy, H., Taravel, F. R., and Vuong, R. (2001). Linear mannan in the endosperm of Schizolobium amazonicum. Carbohydr. Polym. 44, 107-112. doi: 10.1016/S0144-8617(00)00212-5

Pettit, J. M., and Jermy, A. C. (1975). Pollen in hydrophilous angiosperms. Micron 5, 377-405. doi: 10.1016/0047-7206(74)90023-5

Pettitt, J. M. (1980). Reproduction in seagrasses: nature of the pollen and receptive surface of the stigma in the Hydrocharitaceae. Ann. Bot. 45, 257-271. doi: 10.1093/oxfordjournals.aob.a085822

Pfeifer, L., Shafee, T., Johnson, K., Bacic, T., and Classen, B. (2020). Arabinogalactan-proteins of Zostera marina L. contain unique glycan structures and provide insight into adaption processes to saline environments. Sci. Rep. 10:8232. doi: 10.1038/s41598-020-65135-5

Pomin, V.H. (2012). "Chapter 12-structure-function relationship of anticoagulant and antithrombotic well-defined sulfated polysaccharides from marine invertebrates," in Marine Medical Foods: Implications and Applications-Animals and Microbes, ed. K. Se-Kwon (Amsterdam: Academic Press), 195-209.

Popov, S., Popova, G., Golovchenko, V., and Ovodova, R. (2007). Preventative antiinflammatory effect of pectic galacturonans after oral administration. Planta Med. 73:P-015. doi: 10.1055/s-2007-986797

Popper, Z. A., and Fry, S. C. (2004). Primary cell wall composition of pteridophytes and spermatophytes. New Phytol. 164, 165-174. doi: 10.1111/j.1469-8137.2004. 01146.x

Popper, Z. A., and Fry, S. C. (2008). Xyloglucan - pectin linkages are formed intraprotoplasmatically, contribute to wall-assembly, and remain stable in the cell wall. Planta 227, 781-794. doi: 10.1007/s00425-007-0656-2

Raimundo, S. C., Avci, U., Hopper, C., Pattathil, S., Hahn, M. G., and Popper, Z. A. (2016). Immunolocalization of cell wall carbohydrate epitopes in seaweeds: presence of land plant epitopes in Fucus vesiculosus L. (Phaeophyceae). Planta 243, 337-354. doi: 10.1007/s00425-015-2412-3

Sablok, G., Hayward, R. J., Davey, P. A., Santos, R. P., Schliep, M., Larkum, A., et al. (2018). SeagrassDB: an open-source transcriptomics landscape for phylogenetically profiled seagrasses and aquatic plants. Sci. Rep. 6:2749. doi: 10.1038/s41598-017-18782-0

Saijonkari-Pahkala, K. (2008). Non-wood plants as raw material for pulp and paper. Agr. Food Sci. 10:101. doi: 10.23986/afsci.5707

Salmean, A. A., Duffieux, D., Harholt, J., Qin, F., Michel, G., Czjek, M., et al. (2017). Insoluble $(1 \rightarrow 3)$, $(1 \rightarrow 4)-\beta$-D-glucan is a component of cell walls in brown algae (Phaeophyceae) and is masked by alginates in tissues. Sci. Rep. 7:2880. doi: 10.1038/s41598-017-03081-5

Serrano, O., Rozaimi, M., Lavery, P. S., and Smernik, R. J. (2020). Organic chemistry insights for the exceptional soil carbon storage of the seagrass Posidonia australis. Estuar. Coast. Shelf Sci. 237:106662. doi: 10.1016/j.ecss.2020. 106662

Silva, J. M. C., Dantas-Santos, N., Gomes, D. L., Costa, L. S., Cordeiro, S. L., Costa, M. S. S. P., et al. (2012). Biological activities of the sulfated polysaccharide from the vascular plant Halodule wrightii. Rev. Bras. Farmacogn. 22, 94-101. doi: 10.1590/S0102-695X2011005000199

Smith, M. M., and McCully, M. E. (1978). A critical evalutation of the specifity of aniline blue induced fluorescence. Protoplasma 95, 229-254. doi: 10.1007/ BF01294453

Stone, B., and Clarke, A. E. (1992). Chemistry and Biology of (1 $\rightarrow$ 3)-[Beta]-Glucans. Bundoora, VIC: La Trobe University Press.

Strasser, R. (2014). Biological significance of complex $N$-glycans in plants and their impact on plant physiology. Front. Plant Sci. 5:363. doi: 10.3389/fpls.2014. 00363

Syed, N. N. F., Zakaria, M. H., and Bujang, J. S. (2016). Fiber characteristics and papermaking of seagrass using Hand-beaten and blended pulp. Bioresources 11, 5358-5380. doi: 10.15376/biores.11.2.5358-5380

The Plant List (2020). Ruppia. Available online at: http://www.theplantlist.org/1.1/ browse/A/Ruppiaceae/Ruppia/ (accessed September 22, 2020).

Torbatinejad, N. M., Annison, G., Rutherfurd-Markwick, K., and Sabine, J. R. (2007). Structural constituents of the seagrass Posidonia australis. J. Agric. Food Chem. 55, 4021-4026. doi: 10.1021/jf063061a 
Torbatinejad, N. M., and Sabine, J. R. (2001). Laboratory evaluation of some marine plants on South Australian Beaches. J. Agric. Sci. Technol. 3, 91-100.

Tryfona, T., Sorieul, M., Feijao, C., Stott, K., Rubtsov, D. V., Anders, N., et al. (2019). Development of an oligosaccharide library to characterize the structural variation in glucuronoarabinoxylan in the cell walls of vegetative tissues in grasses. Biotechnol. Biofuels 12:109. doi: 10.1186/s13068-019-1451-6

van Erven, G., de Visser, R., Merkx, D. W. H., Strolenberg, W., de Gijsel, P., Gruppen, H., et al. (2017). Quantification of lignin and ist structural features in plant biomass using ${ }^{13} \mathrm{C}$ lignin as internal standard for pyrolysis-GC-SIM-MS. Anal. Chem. 89, 10907-10916. doi: 10.1021/acs.analchem.7b02632

Verma, D. P. S., and Hong, Z. (2001). Plant callose synthase complexes. Plant Mol. Biol. 47, 693-701. doi: 10.1023/A:1013679111111

Waldron, K. W., Baydoun, E. A.-H., and Brett, C. T. (1989). Comparison of cell wall composition of tissues from the seagrasses Halophila and Halodule. Aquat. Bot. 35, 209-218.

Webster, J., and Stone, B. A. (1994). Isolation, histochemistry and monosaccharide composition of the walls of root hairs from Heterozostera tasmanica (Martens ex Aschers.) den Hartog. Aquat. Bot. 39-52. doi: 10.1016/0304-3770(94)90047-7

Wefers, D., and Bunzel, M. (2016). NMR spectroscopic profiling of arabinan and galactan Structural Elements. J. Agric. Food Chem. 64, 9559-9568. doi: 10.1021/ acs.jafc.6b04232

Weng, J.-K., and Chapple, C. (2010). The origin and evolution of lignin biosynthesis. New Phytol. 187, 273-285. doi: 10.1111/j.1469-8137.2010.03327.x

Willats, W. G. T., McCartney, L., Mackie, W., and Knox, J. P. (2001). Pectin: cell biology and prospects for functional analysis. Plant Mol. Biol. 47, 9-27. doi: 10.1023/A:1010662911148

Williams, S. L. (2016). From sea to sea. Nature 530, 290-291. doi: 10.1038/ nature16869

Wissler, L., Dattolo, E., Moore, A. D., Reusch, T. B. H., Olsen, J. L., Migliaccio, M., et al. (2009). Dr. Zompo: an online data repository for Zostera marina and Posidonia oceanica ESTs. Database 2009:bap009. doi: 10.1093/database/bap009
Woolard, G. R., and Jones, J. K. N. (1978). Polysaccharides of the sea grass Phyllospadix torreyi. Carbohydr. Res. 63, 327-332. doi: 10.1016/S0008-6215(00) 80964-7

Wu, S.-W., Kumar, R., Iswanto, A. B. B., and Jae-Yean Kim, J.-Y. (2018). Callose balancing at plasmodesmata. J. Exp. Bot. 69, 5325-5339. doi: 10.1093/jxb/ ery317

Wyllie-Echeverria, S., and Cox, P. A. (1999). The seagrass (Zostera marina [Zosteraceae]) industry of Nova Scotia (1907-1960). Econ. Bot. 53:419. doi: 10.1007/BF02866721

York, W. S., and O'Neill, M. A. (2008). Biochemical control of xylan biosynthesis which end is up? Curr. Opin. Plant Biol. 11, 258-265. doi: 10.1016/j.pbi.2008.02. 007

Yoshiie, T., Maeda, M., Kimura, M., Hama, Y., Uchida, M., and Kimura, Y. (2012). Structural features of $N$-Glycans of seaweed glycoproteins: predominant occurrence of High-Mannose Type $\mathrm{N}$-glycans in marine plants. Biosci. Biotech. Bioch. 76, 1996-1998. doi: 10.1271/bbb.120463

Zidorn, C. (2016). Secondary metabolites of seagrasses (Alismatales and Potamogetonales; Alismatidae): chemical diversity, bioactivity, and ecological function. Phytochemistry 214, 5-28. doi: 10.1016/j.phytochem.2016. 02.004

Conflict of Interest: The authors declare that the research was conducted in the absence of any commercial or financial relationships that could be construed as a potential conflict of interest.

Copyright (C) 2020 Pfeifer and Classen. This is an open-access article distributed under the terms of the Creative Commons Attribution License (CC BY). The use, distribution or reproduction in other forums is permitted, provided the original author(s) and the copyright owner(s) are credited and that the original publication in this journal is cited, in accordance with accepted academic practice. No use, distribution or reproduction is permitted which does not comply with these terms. 